NBER WORKING PAPER SERIES

\author{
ARE BANKS DEAD? OR ARE THE \\ REPORTS GREATLY EXAGGERATED?
}

\author{
John H. Boyd \\ Mark Gertler
}

Working Paper No. 5045

\author{
NATIONAL BUREAU OF ECONOMIC RESEARCH \\ 1050 Massachusetts Avenue \\ Cambridge, MA 02138 \\ February 1995
}

This paper is part of NBER's research programs in Corporate Finance and Monetary Economics. Any opinions expressed are those of the authors and not those of the National Bureau of Economic Research.

(c) 1995 by John H. Boyd and Mark Gertler. All rights reserved. Short sections of text, not to exceed two paragraphs, may be quoted without explicit permission provided that full credit, including $\odot$ notice, is given to the source. 


\title{
ARE BANKS DEAD? OR ARE THE REPORTS GREATLY EXAGGERATED?
}

\begin{abstract}
This paper reexamines the conventional wisdom that commercial banking is an industry in severe decline. We find that a careful reading of the evidence does not justify this conclusion. It is true that on-balance sheet assets held by commercial banks have declined as a share of total intermediary assets. But this measure overstates any drop in banking, for three reasons. First, it ignores the rapid growth in commercial banks' off-balance sheet activities. Second, it fails to take account of the substantial growth in off-shore C\&I lending by foreign banks. Third, it ignores the fact that over the last several decades financial intermediation has grown rapidly relative to the rest of the economy. We find that after adjusting the measure of bank assets to account for these considerations there is no clear evidence of secular decline. To corroborate these findings, we also construct an alternative measure of the importance of banking, using data from the national income accounts. Again, we find no clear evidence of a sustained decline. At most the industry may have suffered a slight loss of market share over the last decade. But as we discuss, this loss may reflect a transitory response to a series of adverse shocks and the phasing in of new regulatory requirements, rather than the beginning of a permanent decline.

John H. Boyd Research Department Federal Reserve Bank of Minneapolis 250 Marquette Avenue Minneapolis, MN 55480

Mark Gertler Department of Economics New York University 269 Mercer Street, 7th Floor New York, NY 10003 and NBER
\end{abstract}




\section{Are Banks Dead? \\ Or Are the Reports Greatly Exaggerated?*}

John H. Boyd $\dagger$

Senior Research Officer

Research Department

Federal Reserve Bank of Minneapolis

\author{
Mark Gertler \\ Professor of Economics \\ New York University \\ and Research Associate \\ National Bureau of Economic Research
}

It is widely believed that in the United States, commercial banking is a declining industry. Two factors are often cited to support this contention. First, nonbank credit alternatives have grown rapidly over the last 15 years. Second, in the late 1980s, banks experienced record levels of failures and loan losses, symptoms of an industry in distress.

The view that banks are declining in importance is held by banking executives, academics, and high officials in many branches of government. For example, William Isaac, former chairman of the Federal Deposit Insurance Corporation and now a prominent banking consultant, was recently quoted as saying that "the banking industry is becoming irrelevant economically, and it's almost irrelevant politically" (Bacon 1993, p. A1). Carter Golembe, the dean of bank consultants, similarly noted "the major problems faced by the banking industry, most notably its eroding competitive position in the financial community and the crushing burden of regulation" (Golembe 1993, p. 4).

The purpose of this study is to check the accuracy of the consensus position that banks are becoming less central to the U.S. economy. Our conclusion, based on an analysis of a variety of data, is that there is no evidence of a significant decline in banking within the United States. After 
correcting for a number of measurement issues, we find that commercial banks' share of total financial intermediation in this country has been roughly stable over the last four decades. At most, banks may have suffered a slight loss of market share in the late 1980s and early 1990s. A case can be made, further, that this slight loss in market share was mainly a transitory response to a series of shocks to the banking industry that occurred over this period. And commercial banking has actually risen in importance relative to aggregate economic activity, even over the last 15 years. While banks have maintained a relatively constant share of intermediation, financial intermediation has been growing steadily relative to gross domestic product. ${ }^{1}$

Why should anyone care whether or not the banking industry is in decline? Many industries naturally expand or contract with the passage of time. The demise of the buggy whip and the hula hoop industries was hardly cause for great concern. Commercial banks, however, have traditionally played a central role in the financial system. They have been key providers of liquidity. They have also been important conduits for credit flows to households and small- and medium-size businesses. (See Corrigan 1983.) The regulatory policies (such as deposit insurance, discount window lending, and capital requirements) that make up the financial safety net stem from the premise that banks are critical to the flow of credit, particularly short-term credit. If technological change and financial innovation are making banks irrelevant, then, at a minimum, rethinking regulatory policy is necessary. Perhaps, focusing the financial safety net around commercial banks is no longer correct. Perhaps, a safety net is no longer necessary. However, if excessive regulation is producing a decline, then relaxing some of these restrictions might be desirable. ${ }^{2}$ Under either scenario, we must know the facts-is banking declining or not? Answering this question is what this article is about. 
Why do our results run counter to conventional wisdom? Formal evidence for the traditional view comes from analyzing the ratio of bank assets to other forms of credit. There are, however, two major problems with this metric.

One problem is that traditional measures of bank assets fail to account for banks' off-balance sheet activities. Over the last 15 years, banks have increased the extent to which they do business off the balance sheet. (See Boyd and Gertler 1993, 1994.) The combination of deregulation and financial innovation has permitted banks to increasingly decouple the various functions involved in intermediating lending. For example, banks now sell some of the loans they originate to other financial institutions. They have also increased the extent to which they indirectly support lending by providing backup lines of credit and guarantees. They now facilitate risk-sharing through the provision of derivative instruments. The result is that industry-share measures based on on-balance sheet assets understate commercial banks' contribution. We show that a good fraction of what appears to have been a decline in commercial banks' share of intermediation by traditional measures instead reflects a relative movement of bank activities from on to off the balance sheet.

The other problem with this metric involves the expansion of lending by foreign commercial banks to U.S. firms that occurred over the 1980s. The increased foreign involvement has contributed to mismeasurement of commercial banks' share of domestic credit flows. The official measures have significantly understated the rise in loans supplied by foreign commercial banks (McCauley and Seth 1992). As we will document, after correcting for both the mismeasurement of foreign bank loans and the exclusion of off-balance sheet activities, any evidence of a substantial decline in commercial banks' share of intermediated assets vanishes.

It is also important to emphasize that proponents of the consensus view have tended to incorrectly use market share of intermediation numbers to draw inferences about banks' importance 
to the economy. As we implied earlier, market-share numbers fail to account for the relative growth of financial intermediation. Indeed, we find that even the unadjusted balance sheet measures indicate no decline in bank assets relative to gross domestic product. And our adjusted measures indicate a clear increase.

In this paper, we first construct measures of bank assets that are designed to properly account for off-balance sheet activities and for total U.S. lending by foreign banks. We then analyze the behavior of this newly constructed aggregate relative to other forms of credit and to gross domestic product. For robustness, we construct credit equivalents of off-balance sheet aetivities using two quite different methods that yield very similar results.

To obtain further evidence on the robustness of results, we then present a completely different approach to measuring banks' importance, using data from the national income accounts (in place of balance sheet data). We use value-added numbers to measure banks' contribution to economic activity. Computations based on this approach give an impression that is very similar to that provided by the augmented balance sheet data: there is no evidence of a secular decline. Because of possible measurement problems with the value-added data, we also do computations based on input usage. Again, there is no evidence of a secular decline.

A number of shocks have certainly jolted the banking industry in recent years, including increased competition, loan losses, and the phasing in of new regulatory requirements. We next assess the impact of these shocks on the condition of commercial banking. We conclude that these factors may have accounted for the slight loss in banks' share of intermediation over this period. But there is no evidence to suggest that these shocks have pushed the industry into permanent decline. Indeed, in the last two years or so, the fortunes of banks have steadily improved, along with the 
overall economy. Thus we cite other reasons to be optimistic about the future of banking and end with some concluding remarks.

Before proceeding, we wish to emphasize that our measures of banking within the United States include the activities of foreign-owned as well as domestically owned entities. We include these because we wish to capture all bank activity that occurs within U.S. borders. Thus all our conclusions apply to the aggregate level of banking within the United States and not to the breakdown of U.S. banking between foreign and domestic ownership. While there may not have been any significant decline in banking within the United States, it is true that the share of business absorbed by foreign-owned banks increased significantly. This phenomenon, however, does not imply that banking has become obsolete; it implies only that the mix of ownership has changed. In a later section, we argue that the trend in ownership is likely to reverse course in favor of domestically owned banks and that the most recently available evidence supports this conjecture.

\section{Adjusted Balance Sheet Measures}

Chart 1 shows the shares of (on-balance sheet) U.S. financial assets held by the different types of private financial intermediaries over the period 1957-93. It clearly reveals the source of the conventional wisdom. In 1974, bank assets amounted to 45 percent of total intermediated claims. Since then, the bank share has steadily declined, falling to 34 percent in 1992. Some types of intermediaries, notably finance companies, increased their market share dramatically. However, the thrift industry (primarily savings and loan associations) lost more relative ground than did banks over this period. ${ }^{3}$

Chart 2 offers a different perspective. It plots the ratios of commercial bank assets to nominal gross domestic product (GDP) and of commercial bank loans to nominal GDP. Both ratios have 
increased over the last four decades. The ratio of bank assets to nominal GDP rose from 0.38 in 1957 to 0.49 in 1992 , and the ratio of bank loans to nominal GDP rose from 0.21 to 0.33 . Both ratios are currently about the same as they as were in 1974. Thus, perhaps contrary to popular thinking, the unadjusted balance sheet numbers do not indicate a decline in banking relative to overall economic activity since 1974 ; they only indicate a loss in market share. ${ }^{4}$ It is important to keep this distinction in mind.

The unadjusted numbers do indicate a drop-off in the ratio of bank loans to nominal GDP, beginning in 1986. However, this drop-off just offsets the rise that occurred in the (roughly) eight years prior. We defer a detailed analysis of the recent behavior of bank loans until the next-to-last section. In the meantime, we simply note that a similar sharp drop-off in the ratio of bank loans occurred around the time of the $1974-75$ recession. In the 10 years following that episode, the ratio rose by nearly one-third.

In the rest of this section, we adjust the measure of bank assets to account for off-balance sheet activities (using two different procedures) and for the underreporting of foreign loans. The adjusted series paint a different picture. Adjusted bank assets have been growing roughly in accord with other forms of financial intermediation over the last four decades. And they have been rising relative to national output. Our adjusted series are not free of measurement problems, as we discuss. However, we offer reasons to think that, if anything, these estimates are conservative.

\section{Estimated Off-Balance Sheet Activities}

A salient feature of commercial banking over the last several decades has been the growth and evolution of off-balance sheet activities. Generally speaking, off-balance sheet activities unbundle the intermediation processs. The key implication for our purposes is that on-balance sheet assets may no longer be a reliable indicator of banks' role in financial intermediation. 
The traditional tasks involved in intermediating a loan include origination (for example, screening the borrower), obtaining loanable funds from savers, monitoring the loan (which may involve holding the loan on the balance sheet), and asset transformation (providing savers with a security that may differ in risk and liquidity from the loan that the bank makes). There are a variety of types of off-balance sheet activities. Each involves segmenting off one or more of these intermediary functions.

Banks, for example, may originate loans but then sell them to other financial institutions. Sometimes the loan is sold in the same form that it is originated (for example, a private placement). If the loan has fairly standard features and is well collateralized (for example, an automobile loan or a mortgage), then the bank may pool it in with similar loans and sell it as part of a securitized package.

Another important way that banks facilitate intermediation without directly holding loans is by providing collateral in the form of backup lines of credit or guarantees. A good example of this phenomenon involves the growth of commercial paper. Over the last 20 years, working capital lending to high-grade companies has shifted away from banks and toward the commercial paper market. Banks have remained in the picture, however, by providing required backup lines of credit and/or guarantees for most of these borrowers. ${ }^{5}$ Simple balance sheet measures fail to capture commercial banks' key role in intermediating these funds.

The most rapidly growing off-balance sheet activity-and the one that has attracted the most media attention-is the provision of derivative instruments. (See the box titled "The Role of Derivatives?" for details on how derivatives have affected the growth of off-balance sheet activities.) Provision of derivatives may be viewed as a form of asset transformation, one of the traditional intermediary functions. A simple example is an interest rate swap, in which a borrower may use the 
bank to hedge against the interest rate risk it faces on a variable rate loan. Provision of derivatives differs from traditional asset transformation, of course, in that arrangements for derivative securities take place off the bank's balance sheet.

The behavior of noninterest income reflects the rising importance of off- balance sheet activities. Total bank income can be expressed as the sum of net interest income (earnings from balance sheet assets net of interest costs) and noninterest income (noninterest earnings from off-balance sheet activities). As Chart 3 illustrates, noninterest income as a percentage of bank assets was roughly stable from 1961 to the late 1970 s. Since then, this number has more than doubled, going from about 0.70 percent in 1979 to 1.87 percent in 1992. Similarly, over this period, noninterest income has jumped from less than 20 percent of total income to about 33 percent. It is worth emphasizing that noninterest income grew rapidly over the same time period that banks' share of total credit (in on-balance sheet assets) was falling.

Our objective in this section is to adjust the measure of bank assets to take account of off-balance sheet activities. Because simple, direct measures of the value of off-balance sheet activities are unavailable, we construct two indirect ones. Each method has drawbacks. However, by using two very different approaches, we hope to obtain reasonable, ballpark estimates.

\section{Basel Credit Equivalents}

Regulators have traditionally imposed capital requirements only against on-balance sheet assets. However, the Basel Accord (of 1988) explicitly recognized the changing nature of banking. It introduced the Bank for International Settlements' (BIS) capital standards that require banks to also hold capital against off-balance sheet positions that entail significant risk exposure. The procedure for computing the off-balance sheet capital requirement entails converting a bank's risky off-balance sheet positions into credit equivalents. In effect, a credit equivalent is an estimate of the amount of 
on-balance sheet asset holdings that would result in the same amount of risk exposure for the bank. Once the credit equivalent is computed for a bank, it is multiplied by a percentage capital requirement, just as if it were an on-balance sheet asset.

Our first method uses this Basel credit equivalent, which (for our purposes) is a very useful construct. It provides a measure of off-balance sheet activities in units of on-balance sheet assets. Research staff at the Board of Governors of the Federal Reserve System provided us with estimates of U.S. commercial banks' total Basel credit equivalents for the years 1983-91. (Unfortunately, earlier estimates are unavailable.) Chart 4 expresses the estimated credit equivalents as a percentage of total (on-balance sheet) bank loans. This percentage grew from about 13 percent in 1983 to 19 percent in 1991. Thus, by 1991, the estimated Basel credit equivalent of off-balance sheet activities was approximately 20 percent of the size of on-balance sheet loans. The relative growth in the credit equivalents over this period is consistent with the relative growth in noninterest income portrayed in Chart 3.

The estimated Basel credit equivalents likely understate off-balance sheet activities for several reasons. One is that they exclude certain activities. Only those off-balance sheet activities that are thought to result in significant risk exposure are included. Activities such as loan sales without recourse, loan servicing, consulting, and trust department services receive no weight whatsoever. In this vein, the classification scheme is somewhat arbitrary. For example, loan commitments with a maturity of one year or more are subject to capital requirements. However, loan commitments with shorter maturities receive no capital weight at all and are therefore excluded from the measure of credit equivalents. (Not surprisingly, the banking industry has responded to this regulatory policy by heavily marketing 364-day loan commitments and then periodically rolling them over.) 
Another reason is that the estimated numbers we have obtained may systematically underestimate the actual Basel credit equivalents. Prior to 1990 , banks did not have to publicly disclose all the relevant information needed to compute these numbers. Hence the estimates (by researchers at the Fed Board of Governors) need not correspond to the actual credit equivalents. For the years 1990 and 1991, however, both estimated and actual numbers are available. If these two years are any guide; then the estimates understate the actual values by at least one-third. The actual numbers reveal that credit equivalents for off-balance sheet activities were roughly 30 percent of the size of on-balance sheet bank loans during these two years, instead of the estimated 20 percent. In 1993, the actual number climbed to about 33 percent. $^{6}$

\section{Noninterest Income Capitalization Credit Equivalents}

Our second method uses the behavior of noninterest income relative to net interest income to back out an estimate of off-balance sheet activities. As with the construction of the Basel credit equivalents, the objective is to obtain a measure in units of on-balance sheet assets. The credit equivalent of off-balance sheet activities under this approach is the quantity of on-balance sheet assets that would be required to generate the observed level of noninterest income. This method boils down to using the rate of return on on-balance sheet assets to capitalize noninterest income.

While the noninterest income capitalization method is crude, it has several advantages over the Basel method. One is that since only income and balance sheet data are required, constructing a longer time series of credit equivalents is possible. (Recall that estimates of.Basel credit equivalents are only available back to 1983.) Another advantage is that this method constructs a credit equivalent for the universe of off-balance sheet activities. The Basel method computes credit equivalents for only those activities that regulators think will entail significant risk. The noninterest income capitalization method is therefore not susceptible to regulatory gaming by banks (to avoid capital 
requirements) in the same way as is the Basel method. For example, loan commitments for less than one year, which do not figure into the calculation of the Basel credit equivalents, are captured by the noninterest income capitalization method.

We also emphasize that the capitalization method uses an entirely different data source than does the Basel method. The former employs bank income statements, while the latter makes use of memoranda items that are reported in bank call reports. Comparable results from the two methods would therefore be evidence of robustness.

The algorithm for computing credit equivalents using the capitalization method works as follows: Define $I=$ interest income, $E=$ interest expense, $P=$ loan loss provision, $N=$ noninterest expense, $Y=$ noninterest income, and $A=$ total assets. The accounting definition of profits before taxes, $\pi$, is then

$$
\pi=I-E-P-N+Y \text {. }
$$

Let the subscript $b$ denote on-balance sheet entries and $o$ denote off-balance sheet entries, and note that $I_{b} \equiv I, E_{b} \equiv E, P_{b} \equiv P, Y_{o} \equiv Y$, and $A_{b} \equiv A$, by accounting definition.

Now, assume (counterfactually) that the noninterest income stream $Y$ is being generated by some hypothetical assets, $A_{o}$. Further assume that these assets are identical in all respects to actual on-balance sheet assets, including the mix of liabilities and equity used to finance them. The question is, How large would the hypothetical asset holdings $A_{0}$ have to be to generate the income stream $Y$ ?

Since both on- and off-balance sheet assets are, by assumption, equally profitable, it must be true that

$$
\left(I_{b}-E_{b}-P_{b}-N_{b}\right) / A_{b}=\left(I_{o}-E_{o}-P_{o}-N_{o}\right) / A_{o} .
$$


Note that the variables $N_{b}$ and $N_{o}$ are not observable in published accounting statements; the only variable that is available is total noninterest income, $N$. However, because of the assumption of symmetry between on- and off-balance sheet assets, it must be true that

$$
N_{b} / A_{b}=N_{o} / A_{o}
$$

Combining equations (2) and (3) and rearranging, we get

$$
A_{o}=A_{b}\left(I_{o}-E_{o}-P_{o}\right) /\left(I_{b}-E_{b}-P_{b}\right)
$$

The denominator in (4) is net interest income minus loan loss provisions, and these variables all appear in accounting statements. $I_{o}, E_{o}$, and $P_{o}$ are not separately observable, but the variable $Y$ is the net amount of income generated by off-balance sheet activities, before deducting noninterest expense. Therefore,

(5) $\quad Y=I_{o}-E_{o}-P_{o}$.

Substituting (5) into (4), we get

$$
A_{o}=A_{b}[Y /(I-E-P)]
$$

All the variables on the right side of (6) can be observed, and this is the expression used to estimate off-balance sheet credit equivalents, $A_{0}$.

We refer to $A_{o}$ as the NIC-1 credit equivalent (for noninterest income capitalization, method 1). Chart 5 plots the ratio of this credit equivalent to on-balance sheet loans, over the time frame 1961-93. Not surprisingly, this ratio closely mirrors the normalized value of noninterest income portrayed in Chart 3. It is fairly flat until the mid-1970s and then rises sharply from about 0.30 in 1978 to about 0.92 in 1993 . 
Over the 1980 s, the NIC-1 credit equivalent is also qualitatively similar to the behavior of the estimated Basel credit equivalent. (Compare Charts 4 and 5.) Not surprisingly, the capitalization method yields a larger estimate than does the Basel method. [Recall from our earlier discussion that the latter captures only risky off-balance sheet activities (by regulatory definition).]

To obtain a credit equivalent that can be more directly compared to the Basel credit equivalent, we make the following adjustment to NIC-1. We attempt to eliminate from NIC-1 the nonrisky off-balance sheet activities that the Basel numbers do not capture. We first assume (reasonably) that off-balance sheet activities prior to 1970 were primarily safe, plain-vanilla services (for example, trust department services). We then use the period 1961-70 to obtain an estimate of the ratio of the credit equivalent of these safe activities to on-balance sheet assets. This task involves taking an average of the ratio $[Y /(I-E-P)]$ over this period. [See (6).] Call this ratio $\alpha$. Then $\alpha A$ is an estimate of the credit equivalent of these plain-vanilla activities, if we assume that these activities remain in fairly stable proportion to balance sheet assets. (Note that over the period 1961-70, the ratio $\alpha$ was reasonably stable.) Finally, to obtain a credit equivalent that is adjusted to capture only risky activities, we subtract $\alpha A$ from $A_{o}$ in (6). Call the adjusted number $A(\operatorname{adj})$. Thus

$$
A(\operatorname{adj})=A_{o}-\alpha A=[Y /(I-E-P)-\alpha] A .
$$

For consistency, we refer to $A(\mathrm{adj})$ as the $N I C-2$ credit equivalent (for noninterest income capitalization, method 2). Chart 5 also plots the NIC-2 credit equivalent as a fraction of on-balance sheet loans. ${ }^{7}$

\section{Underreported Offshore Foreign Loans}

It is no secret that over the last decade, foreign banks have significantly increased their operations within the United States. Until very recently, however, few observers fully appreciated the magnitude of foreign bank intermediation. A study by McCauley and Seth (1992) showed that the official 
numbers greatly understated foreign involvement. In particular, there has been minimal accounting for loans by foreign banks that were booked offshore. For a number of years, U.S. offices of foreign banks could avoid all U.S. reserve requirements if they booked loans outside the United States at their home offices or in tax havens. Unfortunately, the official U.S. statistical sources, including the flow of funds accounts, did not capture such offshore bookings. ${ }^{8}$

McCauley and Seth obtained data from the U.S. Treasury that avoid this measurement problem. The Treasury collects data from U.S. borrowers, not from banks. Therefore, its numbers - include the offshore bookings. Chart 6 shows that the discrepancy between the actual and the officially measured quantity of foreign bank loans was quite large. And the discrepancy grew over the last decade. In 1983, the unadjusted share of bank assets held by foreign banks was about 5 percent, while the adjusted share (which took account of offshore loans) was 9 percent. In 1992, the unadjusted share was 11 percent, while the adjusted share jumped to 21 percent. By 1993, unreported offshore commercial loans totaled $\$ 175$ billion. (See Table A1 in the Appendix.)

Since the offshore foreign loans reflect loans to U.S. firms that are intermediated by commercial banks, they should be added to our adjusted measure of bank credit. Here our goal is to measure the importance of commercial banks to the U.S. economy. The rise in the foreign share over the 1980s may have reflected increased competition for domestic banks, but it did not in any way reflect a decline in the role of banking.

How the bank credit flows are divided between foreign and domestic entities is an interesting issue, but one that is beyond our focus. We do, however, conjecture that for several reasons, the foreign share of banking is likely to decline. ${ }^{9}$ One reason is that a number of the regulatory differences that favored foreign banks have been eliminated (for example, differential reserve requirements and capital requirements). Another reason is that the U.S. trade deficit, which, no 
doubt, accounted for some of the rise in the share of foreign lending during the 1980s, appears to be reversing course.

\section{Adjusted Measures of Total Bank Assets}

We now present measures of total bank assets that adjust for both off-balance sheet activities and unreported offshore loans. We construct two aggregates: one that uses the Basel estimates to generate credit equivalents for off-balance sheet assets and another that uses the noninterest income capitalization method. We then use the adjusted aggregates to recompute the following: (i) banks' share of total intermediated assets and (ii) the magnitude of bank credit relative to GDP.

Chart 7 plots the adjusted share of commercial bank assets in total financial intermediation, relative to the unadjusted share. In this chart, we use the NIC-2 credit equivalent to illustrate the effect of the capitalization method, since this aggregate corresponds best to the Basel credit equivalent. (Recall that NIC-2 is a rough attempt to isolate risky off-balance sheet activities.) The two methods yield similar results-though, as expected, the NIC-2 method produces a larger change than does the Basel method. The Basel method eliminates about one-half of the decline in bank share that occurred since the peak in 1974, and the NIC-2 method eliminates nearly all of it. And viewed from the context of the entire four decades, the decline in the bank share since the peak in 1974 is quite modest. The average bank share over this period is fairly stable, averaging slightly greater than 40 percent.

We also compare the relative importance of correcting for off-balance sheet activities versus correcting for offshore foreign lending. (See Table A2 in the Appendix.) Each correction accounts for about one-half of the deviation of the adjusted bank share number from the unadjusted number in Chart 7 when the Basel method is employed. With the NIC-2 method, the off-balance sheet 
correction accounts for about two-thirds of the difference, and the foreign lending correction explains the remaining one-third.

Chart 8 repeats the exercise portrayed in Chart 7, this time normalizing the adjusted measures of bank assets relative to GDP. While the unadjusted ratio flattens out after 1975 , the two adjusted ratios continue to rise. Thus, relative to GDP, commercial banking appears to have increased in importance. As in the previous case, using either the Basel or the NIC-2 credit equivalent to account for off-balance sheet activities appears to generate similar results; however, the NIC-2 method produces a somewhat larger change.

We also plot the ratios of adjusted bank assets to total intermediary assets and adjusted bank assets to nominal GDP. Here we use the NIC-1 credit equivalent, which is the comprehensive measure of off-balance sheet activities. (See Charts A1 and A2 in the Appendix.) This time we do not include the Basel-adjusted ratios in the charts, since the Basel credit equivalent does not correspond closely to the NIC-1 credit equivalent. From roughly 1961 to 1978 , the adjusted series for each ratio is simply an upward, parallel shift of the unadjusted series. After about 1978, the gap steadily widens, as off-balance sheet activities grow in importance. ${ }^{10}$

We readily acknowledge that our adjustments to the flow of funds balance sheet data are crude. Nonetheless, it is reassuring that two very different approaches to accounting for off-balance sheet activities yield rather similar results. Our numbers may be biased, however, in that we have not been able to take account of off-balance sheet activities of other financial intermediaries due to a lack of data availability. Insurance companies, in particular, have been active in issuing letters of credit and other financial and performance guarantees. Thus our adjusted numbers may overstate banks' share of intermediated asset holdings. This consideration, however, does not affect our rough measure of banks' importance to the overall economy, that is, the ratio of bank assets to GDP. We 
also emphasize that both the Basel and the NIC-2 credit equivalents used in the calculations underlying Charts 7 and 8 account for only a subset of banks' off-balance sheet activities. Only the NIC-1 credit equivalents that we used are, in principle, comprehensive. (Again, see Charts A1 and A2 in the Appendix.)

In the next section, we pursue an entirely different approach to measuring the importance of banking using data from the national income accounts. (See Table A3 in the Appendix.) ${ }^{11}$

\section{Value-Added Measure}

Our goal in this section is to measure the economic output-or value-added—of commercial banks, using information from the national income accounts.

The national income accounts provide information on the value-added of different sectors of the economy, including the financial sector. The series began in 1947 . The finance sector data include separate information for depository institutions, insurance companies, brokers, and other credit intermediaries. At present, these subsector value-added data are only available through 1990.

Because a total sales figure is unavailable for financial intermediaries, one cannot compute their value-added using standard methods. Instead, value-added for this sector is represented by the sum of payments to all factors of production, which are composed primarily of wages and salaries, profits, interest expense, and depreciation. ${ }^{12}$

We emphasize that the value-added approach to measurement is quite different from the balance sheet approach we employed in the previous section. Not only are the data sources different, but so is the underlying conceptual basis. Indeed, the value-added approach is, in principle, the purest way to identify banks' contribution. Unlike the balance sheet approach, it naturally adjusts for changes in the nature of bank activities. For example, a dollar's worth of bank employee labor is treated the same, whether it is paid to a teller or to a swap trader. Therefore, the value-added 
measure will capture all off-balance sheet activities of banks and other financial intermediaries (thus eliminating one important potential source of bias in our previous analysis). Moreover, the valueadded measure should capture changes in the composition of on-balance sheet assets for banks and other intermediaries. For commercial banks, the trend has been to move out of lower-risk lending into higher-risk, information-intensive lending. (For examples of this trend, see Boyd and Gertler 1993, 1994.) Value-added per dollar of assets is likely higher for the latter activity than for the former.

Unfortunately, the national income accounts do not maintain sectoral data for commercial banks by themselves. What are called banks in these accounts (and in our Charts 9-14) include commercial banks, Federal Reserve banks, and mutual savings banks. And these data are only available through 1987. After that date, changes in standard industrial classifications were made. Therefore, to obtain a banking industry series that is historically consistent and goes beyond 1987, we must examine an even more inclusive aggregate. We call this aggregate banks +credit. It includes banks as defined above plus savings and loans, credit unions, business credit institutions, mortgage banks, and rediscounting agencies (such as the Federal National Mortgage Association and the Government National Mortgage Association). ${ }^{13}$

Chart 9 shows the value added by the banking industry, expressed as a percentage of the total value added by the financial intermediary sector. Both banking industry definitions are shown in the chart, and both are highly correlated. The main thing to observe from Chart 9 is that over the long run, banks' share of value-added has remained fairly constant, if anything, increasing somewhat over time. Linear time trends fitted through both series display positive slopes.

There is a long-standing controversy about national income accounting for financial intermediaries and about the accuracy of value-added computations for firms in this sector. ${ }^{14}$ In light 
of the continuing debate, it is useful to investigate trends in factor inputs of firms in these industries as well as their output. Factor inputs for financial intermediaries are measured in the usual way and are not particularly subject to error relative to other industries. Chart 10 shows banks' share of total employment (with full- and part-time equivalents) as a percentage of total employment in financial intermediary firms. The long-term trend in banks' share of employment displays a positive slope, according to either measure. However, it appears to have made a modest drop in the 1980 s. For example, the share of banks +credit dropped from just over 50 percent in 1983 to about 47 percent in 1992.

Chart 11 shows banks' shàre of total investment in plant and equipment as a percentage of total plant and equipment investment in the financial intermediary sector. These numbers are net of depreciation and are adjusted for the effects of inflation. The picture here is very much like that for employment (in Chart 10). That is, the long-run trend is positive, according to either measure. However, in the early 1980 s, both measures fall below trend. It is worth noting that the input-share measures for banks drop around 1980, whereas their share of value-added is actually above trend in the 1980s. We are not sure of the explanation for the difference between recent trends in industry inputs and outputs. What is clear, however, is that, according to any of these measures, there is no evidence that commercial banking has lost market share over the long run. All six fitted time trends in Charts 9-11 display positive slopes.

As with the balance sheet data, if we scale banks' importance relative to the national economy instead of to other intermediaries, the picture is even brighter. Consider the growth of the financial intermediary sector relative to the total economy, as in Chart 12 . The chart shows the value added by the financial intermediary sector as a percentage of total GDP. This percentage has increased substantially over the sample period, in fact, more than doubling. However, the same is true for 
either measure of banks' share of the value added to total GDP. As shown in Charts 13 and 14, the same result (much more rapid growth than the overall economy) is displayed by the factors of production of the intermediary sector and of bank-related firms. The growth in capital investment has been particularly dramatic. These data, therefore, consistently suggest that the financial intermediary sector, including banks, has been a growth industry, relative to the overall economy.

\section{Implications of the Recent Bank Lending Slowdown}

Both the adjusted balance sheet data and the national income accounts data suggest that, at most, there has been a slight decline in commercial banks' share of financial intermediation over the last decade. And, if anything, banking as a component of GDP has risen in importance. Nonetheless, from 1986 to 1992 , there was a fairly substantial drop in the growth rate of (on-balance sheet) commercial bank lending. The measurement issues that we emphasized in the adjusted balance sheet section account for part of this phenomenon. We think the other part may be explained largely by factors that were transitory in nature. There is no clear reason to believe that it is symptomatic of a major decline in banking.

Chart 15 plots the growth rates of real bank loans, bank assets, and total financial intermediary assets over the period 1957-92. From 1986 on, the growth rate of bank loans steadily declines, becoming negative in 1990 . Most of the decline is due to a drop in commercial and industrial lending. (See Boyd and Gertler 1993, 1994.) However, the commercial paper market, which grew rapidly over this period, absorbed some of this decline. As we have argued earlier, this phenomenon, for the most part, reflects a shift of high-quality commercial and industrial (C\&I) lending from on to off the banks' balance sheets, since banks typically provide continued support with backup credit lines and guarantees. Offshore foreign banks absorbed another portion of the decline. Here, of 
course, the problem is the failure to include the assets of foreign offshore banks in the measure of the aggregate C\&I lending.

Beyond these measurement issues, however, we think that underlying the 1986-92 slowdown in bank lending were at least two other factors that were largely transitory in nature. One involves the recent capital shortage, which (according to numerous authors) was a significant factor in the lending slowdown. The other involves the 1990-91 recession and the associated drop in long-term interest rates. We analyze each in turn.

\section{The Capital Crunch}

In the 1980 s, several factors combined to produce (what many observers claim was) a capital shortage (or a capital crunch) within the banking industry. The first was a series of adverse shocks to bank loan portfolios that substantially depleted bank capital by producing record loan losses for the postwar period. These shocks included the less-developed country (LDC) debt crisis and the collapse of profits in agriculture, oil, and real estate. The second factor was the associated tightening of regulatory standards. In response to the deteriorating condition of depository institutions, regulators tightened supervision and imposed new restrictions. Included among the new restrictions was the Basel Accord (and its new BIS capital standards).

The pressure on capital was particularly acute for large banks. (See Boyd and Gertler 1993, 1994.) These banks suffered disproportionate losses of capital since they had invested heavily in both LDC and commercial real estate lending. Further, even before loan losses piled up, large banks tended to operate with capital/asset ratios that were well below the industry mean. The huge loan losses over the 1980 s simply pushed them further below the mean. Therefore, in the peak years of the capital crunch (1989-91), large banks had to make the greatest effort to satisfy the newly instituted capital standards. 
The significance of the capital crunch for our purposes is that it was a likely factor in the bank lending slowdown. An enormous volume of recent research, beginning with the work of Bernanke and Lown (1991), Furlong (1991), Johnson (1991), and Peek and Rosengren (1991), has identified a connection between bank capital and lending over this period. These papers use panel data on individual banks to estimate loan supply equations that allow for the influence of capital. While there has been debate over the influence of regulatory factors, the link between capital and lending has been found to be fairly robust. Further, this link survives after controlling for variation in loan demand across banks. Finally, Lown and Peristiani (1993) have recently shown that it was mainly among large banks that capital impinged on lending (that is, the link between capital and lending was strongest among large banks). This finding is compatible with the earlier evidence that the capital shortage was likely most acute for large banks.

While it is beyond the scope of this article to add to the formal evidence on this topic, we do think that it is useful to show the link between capital and asset growth that is present in the raw data. As shown in Table 1, undercapitalized banks contracted their assets in each year from 1990 through 1992 and increased them in 1993 at only about a 1 percent rate. Well-capitalized banks, however, exhibited positive rates of asset growth in each of these years, averaging about 5.7 percent. It is, of course, important to distinguish between the behavior of assets and the behavior of loans. Table 1 shows that for the period 1990-93 the differences in loan growth across undercapitalized and well-capitalized banks were roughly the same as the differences in asset growth. In 1991 and 1992, loan growth was below asset growth for all categories, though it was weakest at undercapitalized banks and strongest at well-capitalized banks. Interestingly, in 1993, loan growth picked up substantially for well-capitalized banks, but remained stagnant for the other categories. 
Table 2 reports the connection between size and real asset growth, in the spirit of Lown and Peristiani (1993). (Unfortunately our data disaggregated by size do not perfectly overlap with our data disaggregated by capital adequacy.) The largest banks grew much less rapidly over the 1984-91 period than did the rest of the industry. The average growth rate of balance sheet assets of banks in the over $\$ 10$ billion category was only 0.7 percent, whereas the industry average growth rate was 4.3 percent. To the extent that large banks were, on average, further below regulatory capital limits, we should expect (with everything else being equal) the decline in loan growth to be greatest among these banks. This is, of course, exactly what Lown and Peristiani found. ${ }^{15}$

In summary, there is evidence to suggest that (beyond the measurement problems discussed in the adjusted balance sheet section) the unusual slowdown in bank lending was due, in part, to balance sheet problems experienced primarily by large banks. Much of the adjustment to the capital shortage, however, appears to have taken place. Capital/asset ratios within the industry have improved, partly due to adjustment in assets and partly due to the replenishment of capital. Several years of strong earnings and a favorable equity market are responsible for the latter.

\section{The 1990-91 Recession}

Another key factor underlying the lending slowdown was the 1990-91 recession. Over 1983-91, (unadjusted) real bank assets grew at a uniformly lower rate than did total intermediary assets, as Chart 15 illustrates. However, in the period around the recession, the growth rate of total real financial intermediary assets declined at about the same rate as the growth rate of (unadjusted) real commercial bank assets. This across-the-board decline suggests that falling demand for intermediary loans around this time was partly responsible for the behavior of bank lending. As Chart 15 illustrates, a similar sharp drop in the growth rate of bank assets and bank loans occurred around the 
1974-75 recession. The growth rate of total intermediary assets also fell, suggesting that demand factors were again at work.

We also emphasize that the growth rates of bank loans and bank assets in Chart 15 are not adjusted for the measurement issues raised in the adjusted balance sheet section. Though we do not show the results here, simply adding in corrections for omitted offshore foreign loans and off-balance sheet activities raises the growth rate of bank loans and bank assets by several percentage points over the years from 1987 to 1990 .

Finally, we ask, Why did bank lending not pick up in 1992 and 1993? Is this not evidence. that there has been a fundamental change and that commercial banking is in decline?:We think not. There have been similar episodes (for example, flat or falling loan demand in a recovering economy) in the past. Rising cash flows associated with the recovery add to the supply of internal funds, dampening the need for external finance. For example, bank loans fell precipitously in 1976, the first year of the recovery after the 1974-75 recession. In addition, as we have been suggesting, stagnant lending has not been unique to commercial banks. Table A4 in the Appendix shows that total business lending by nonbank finance companies has been essentially flat since 1991.

There may be several other factors involved that are peculiar to this recovery. One factor is that some loan markets remain depressed. This trend is particularly true of commercial real estate lending, and the problem is much worse in some parts of the country than in others. In the first nine months of 1993, business loans expanded in the Southeast, Midwest, and Southwest, but contracted in the Northeast and Far West (especially California). (The latter two areas were the hardest hit by the commercial real estate crash.) Moreover, most of the contraction in bank business lending has been in construction and land development loans (Board of Governors of the Federal Reserve System 
1993). Whereas delinquency and charge-off rates have fallen since mid-1991, these still remain high by historical standards in some parts of the country.

In response to these conditions, many bank managers have remained cautious about expanding loan portfolios, even as the economy has recovered. The Federal Reserve's survey of terms of bank lending indicates that banks have gradually eased credit terms for large corporate borrowers, but have not done so for smaller corporations. Indeed, the spread of the prime rate over the federal funds rate remains around 300 basis points, which is extremely high by historic standards.

Another factor is that banks have not needed to expand their loan portfolios to earn exceptional profits. (See Table A5 in the Appendix.) Over'the last several years, the yield curve has been very steeply sloped, and banks have been able to earn excellent interest rate spreads on expanded holdings of government- and mortgage-backed securities. Table A6 in the Appendix shows the growth in the ratio of securities to total assets. Various observers have noted the unusual nature of these circumstances and the potential for interest rate risk exposure.

Still another factor is that for the last several years, low long-term interest rates and an associated favorable equity market may have induced substitution away from bank loans. That is, nonfinancial corporations have reduced their dependence on short-term borrowing by issuing longterm debt and new equity. Over the period 1990-93, the fraction of total borrowing obtained by nonfinancial corporations from commercial banks fell by just over 2 percentage points. (See Table A4 in the Appendix.) Similarly, nonbank loans fell by 2.4 percentage points. However, these declines were offset by bonds outstanding, which increased from 37 percent to nearly 42 percent, or about 5 percentage points. ${ }^{16}$

\section{Concluding Remarks}


We do not dispute the notion that the banking industry experienced severe difficulties in the late 1980s. Indeed, our earlier work (Boyd and Gertler 1993, 1994) focused on this issue. What we are calling into question is whether the poor performance over this period signals the beginning of a permanent decline. Both the balance sheet data (adjusted for a variety of measurement issues) and value-added and input data from the national income accounts fail to reveal any striking decline in the role of commercial banks.

Clearly, banks have faced increased competition from nonbank alternatives. They have responded, however, by changing the way they provide traditional services and by developing new products. ${ }^{17}$ The rising importance of off-balance sheet activities, ranging from credit lines to derivative products, are symptomatic of these developments.

In many cases, further, the growth of off-balance sheet activities reflects only superficial rather than substantive changes in the nature of banking. For example, the intermediation aspect of providing backup credit lines or guarantees to commercial paper issuers is not fundamentally different from that of directly providing credit to these high-grade companies. Thus we strongly caution against interpreting movement to off-balance sheet activities as indicating that banks are moving into completely new lines of business and abandoning old ones.

If we are right that banking is not a declining industry, then more than an academic interest is at stake. Important public policy decisions have been and continue to be based on the consensus view. One such policy is in the area of bank mergers. Consolidation in banking (largely via mergers) has been encouraged, partly on the grounds that it is a way to mobilize resources out of a declining industry. If the industry is not declining, only changing, this argument loses force. Another such policy area is the expansion of bank powers. One common argument is that banks are declining because, with current power limitations, they cannot compete. This argument also loses force 
(although there may be other perfectly valid reasons why bank powers should be expanded). Along the same lines, it is often argued that banks cannot compete because of excessive regulatory burden or that interest should be paid on required reserves to help out this troubled industry. Related policy proposals abound, all based on a premise that is questionable. If public policy is based on bad assumptions, it is not likely to be good, except by accident. 


\section{The Role of Derivatives?}

The use of derivatives has exploded over the last few years, at least at a handfiul of large U.S. banks. Does that account for much of the expansion in off-balance sheet activity described in the accompanying paper? Or has that expansion been broadly based?

One type of evidence supports the latter view. Data on the contribution of derivatives to the Basel measures of offbalance sheet activity are available back to 1990 . In these years, derivatives typically account for less than 30 percent of the total. (See Chart 4 in the paper.)

Another type of evidence also supports this view that expansion has been broadly based. The chart shown here plots the growth during 1985-92 in noninterest income across four different asset size classes of banks. If derivatives explain most of the growth in off-balance sheet activity, then we should expect the rise in noninterest income to be concentrated mainly among the 10 largest banks. (They account for almost all the industry's derivative activities, as can be seen in the accompanying table.) However, noninterest income as a percentage of assets has grown across all caregories of banks. True, this rario has grown the fastest for the 10 largest banks (from 1.37 in 1985 to 2.59 in 1992). But the ratio has grown nearty as fast (from 1.32 to 2.25 ) for banks outside the top 10, those with assets exceeding $\$ 5$ billion.

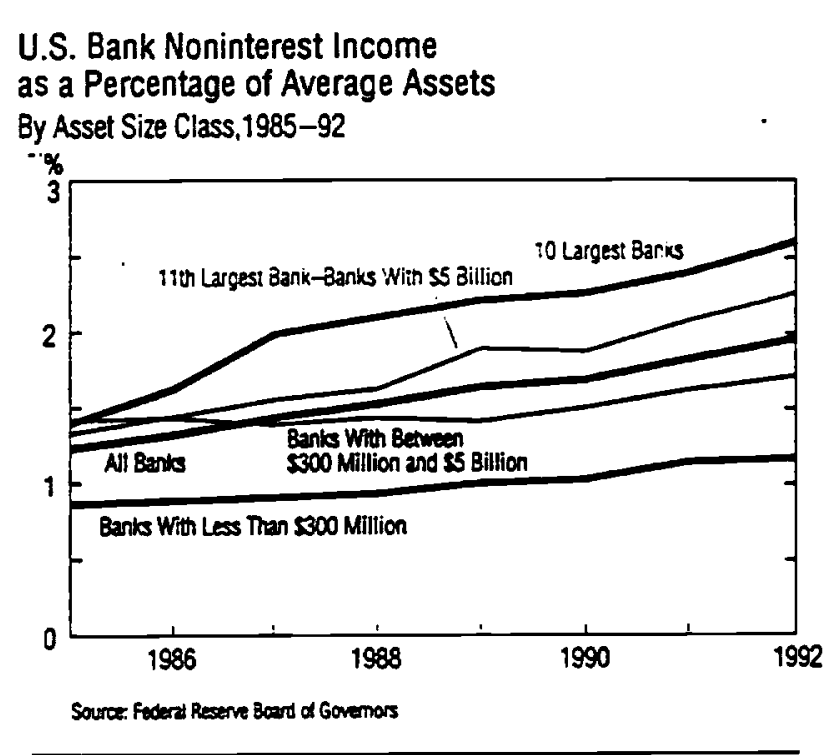

Measures of the 10 Largest U.S. Banks*

in 1993

\begin{tabular}{|c|c|c|c|c|}
\hline & \multirow[b]{2}{*}{ Assets } & \multirow{2}{*}{$\begin{array}{l}\text { Derivative } \\
\text { Securities } \\
\text { Positionst }\end{array}$} & \multicolumn{2}{|c|}{ Credil Equivalent Risk Exposure } \\
\hline & & & Total & $\%$ of Assets \\
\hline Chemical Bank & $\$ 110.4$ & $\$ 2,114.0$ & $\$ 31.9$ & $29 \%$ \\
\hline Bankers Trust Company & 63.9 & $1,802.3$ & 29.5 & 46 \\
\hline Citibank & 168.6 & $1,789.3$ & 38.2 & 23 \\
\hline Morgan Guaranty Trust Company & 103.5 & $1,537.5$ & 37.9 & 37 \\
\hline Chase Mannattan & 79.9 & $1,026.1$ & 23.0 & 29 \\
\hline Banik of America & 134.0 & 893.5 & 21.7 & 16 \\
\hline Fiis: National Bank of Chicago & 34.1 & 457.4 & 10.1 & 30 \\
\hline Continental Bank & 22.0 & 169.9 & 2.5 & $\pi$ \\
\hline Reoublic National Bank of New York & 28.4 & 167.7 & 2.7 & 10 \\
\hline Bank of New York & 35.8 & 92.2 & 1.7 & 5 \\
\hline
\end{tabular}

- Soviz moures in ailions.

- Naliona srincioe possions.

Sarce somerciles $x$ ine interag 


\section{Footnotes}

*We received helpful comments on earlier drafts from Stan Graham, Stuart Greenbaum, Cara Lown, Preston Miller, Art Rolnick, Dave Runkle, Gary Stern, and Neil Wallace. We thank Kerstin Johnsson and Joel Krueger for their excellent assistance with statistical work. We also thank Rama Seth (Federal Reserve Bank of New York) and Robert Yuskavage (Department of Commerce, Bureau of Economic Analysis) for help with data analysis and interpretation. At the Board of Governors of the Federal Reserve System, we are indebted to Jalal Aqhavein, Allen Berger, Jim Embersit, Ed Ettin, Myron Kwast, Tom Simpson, and David Wright. Jody Fahland provided outstanding word processing assistance. Our special thanks go to Ed Ettin who commented on various drafts and provided much support for this study. Of course, we remain solely responsible for any remaining errors.

†Also, Adjunct Professor of Finance, University of Minnesota.

${ }^{1}$ In fairness, we are not the only ones to have recently questioned the consensus view or noted the severe deficiencies of conventional bank accounting data. See, for example, Cates 1993 or Ettin 1994.

${ }^{2}$ Feldstein (1993), for example, makes the case that excessive regulation of banking may have produced harmful effects on the economy.

${ }^{3}$ In Chart 1 , both state and local government pension funds are excluded from the insurance sector (although they are included there in the flow of funds accounts).

${ }^{4}$ Romer and Romer (1993) similarly emphasize that the ratio of bank loans to GDP has not declined over the postwar period.

${ }^{5}$ Commercial bankers have informed us that in recent years, providing guaranteed credit lines for highly rated commercial paper issues can be about as profitable as providing the loan directly. 
That is, fee income on the credit line is roughly as large as net interest income would be on a commercial loan of the same size. Interest rate spreads are generally very thin on large commercial loans to low-risk borrowers.

${ }^{6}$ Beginning in 1990 , banks were required to fully report the information necessary to calculate Basel credit equivalents; prior to that, only estimates were possible. We are indebted to Jalal Aqhavein and Allen Berger for their help in obtaining these estimates.

${ }^{7}$ The adjustment to total bank assets is not greatly affected if the base period (1961-70) for computing $\alpha$ is moved forward or backward a few years.

${ }^{8}$ Recently, the Board of Governors of the Federal Reserve System began collecting and publishing comparable data. See Terrell 1993.

9In fact, Nolle (1994) presents evidence that foreign banks' share has already begun to decline.

${ }^{10}$ In some computations (not reproduced here), NIC-adjusted bank assets were reduced by the amount of their holdings of U.S. government securities and agency issues. Banks' share of financial intermediation and bank assets divided by GDP still displayed almost exactly the same patterns as in Charts A1 and A2. Of course, there is a downward, level shift due to the reduction in adjusted total bank assets.

${ }^{11}$ For completeness, we note here several other types of bank-related assets that do not appear on conventional bank balance sheets. One is assets held by nonbank affiliates of bank holding companies (for example, consumer finance affiliates). As shown in Table A3 in the Appendix, these amounted to $\$ 268$ billion by 1993 (with roughly one-half in the form of securities). Another is loans originated by commercial banks and sold or participated without recourse into the secondary market. In 1993, about $\$ 83$ billion in consumer loans and (at least) $\$ 53$ billion in commercial loans had been sold in this manner. These data on sold loans must be interpreted with extreme caution, however. 
A significant (but unknown) fraction of such loan sales are to other commercial banks. Moreover, data on sales of mortgage loans by commercial banks-undoubtedly a large volume activity-are not currently available.

${ }^{12}$ This method for computing value-added is also employed for many service sectors of the economy.

${ }^{13}$ We thank Robert Yuskgavage for explaining these features of the data to us.

${ }^{14}$ See, for example, Berger and Humphrey 1992 or Fixler and Zieschang 1992.

${ }^{15}$ For more information on the relation between size and performance in banking, also see Boyd and Runkle 1993.

${ }^{16}$ Very recently released data from the Federal Reserve's survey of terms of bank lending suggest a sharp pickup in bank lending, including commercial lending, in many parts of the country.

${ }^{17}$ In Boyd and Gertler 1993, we summarize the arguments that explain why banking continues to occupy a special niche in the financial services industry. After taking into account its (important) indirect role in the commercial paper market, we find that banking remains central to the provision of liquidity. For similar arguments, see Corrigan 1983 and D'Arista and Schlesinger 1992. 


\section{References}

Bacon, Kenneth H. 1993. Losing ground: Banks' declining role in economy worries Fed, may hurt firms. Wall Street Journal (July 9): A1.

Berger, Allen N., and Humphrey, David B. 1992. Measurement and efficiency issues in commercial banking. In Output measurement in the service sectors, ed. Zvi Griliches, pp. 245-79. Chicago: University of Chicago Press.

Bernanke, Ben S., and Lown, Cara S. 1991. The credit crunch. Brookings Papers on Economic Activity 2:205-39.

Board of Governors of the Federal Reserve System. 1993. Credit availability for small businesses and small farms.

Boyd, John H., and Gertler, Mark. 1993. U.S. commercial banking: Trends, cycles, and policy. NBER Macroeconomics Annual 1993: 319-68.

. 1994. The role of large banks in the recent U.S. banking crisis. Federal Reserve Bank of Minneapolis Quarterly Review 18 (Winter): 2-21.

Boyd, John H., and Runkle, David E. 1993. Size and performance of banking firms: Testing the predictions of theory. Journal of Monetary Economics 31 (February): 47-67.

Cates, David. 1993. The Bank Analyst 7 (no. 3): 1. Ferguson and Company.

Corrigan, E. Gerald. 1983. Are banks special? Federal Reserve Bank of Minneapolis 1992 Annual Report: 5-24.

D'Arista, Jane W., and Schlesinger, Tom. 1992. The parallel banking system. Manuscript. Economic Policy Institute, Washington, D.C.

Ettin, Edward C. 1994. The evolution of the North American banking system. Working Paper. Board of Governors of the Federal Reserve System. 
Feldstein, Martin S. 1993. Comment (on Boyd/Gertler paper). NBER Macroeconomics Annual 1993: $372-76$.

Fixler, Dennis J., and Zieschang, Kimberly D. 1992. User costs, shadow prices, and the real output of banks. In Output measurement in the service sectors, ed. Zvi Griliches, pp. 219-44. Chicago: University of Chicago Press.

Furlong, Frederick T. 1991. Can bank capital regulation work? Research revisited. Federal Reserve Bank of San Francisco Economic Review (Summer): 32-33.

Golembe, Carter H. 1993. Golembe Reports 1993-7: 2-4.

Johnson, Ronald. 1991. The' capital gamble. Manuscript. Federal Reserve Bank of New York.

Lown, Cara S., and Peristiani, Stavros. 1993. The 1990 credit slowdown: Did large banks create a credit crunch? Manuscript. Federal Reserve Bank of New York.

McCauley, Robert, and Seth, Rama. 1992. Foreign bank credit to U.S. corporations: The implications of offshore loans. Federal Reserve Bank of New York Quarterly Review 17 (Spring): 52-65.

Nolle, Daniel E. 1994. Are foreign banks out-competing U.S. banks in the U.S. market? Working Paper 94-5. U.S. Comptroller of the Currency.

Peek, Joe, and Rosengren, Eric. 1991. The capital crunch: Neither a borrower nor a lender be. Working Paper 91-4. Federal Reserve Bank of Boston.

Romer, Christina D., and Romer, David H. 1993. Credit channel or credit actions: An interpretation of the postwar transmission mechanism. In Changing capital markets: Implications for monetary policy, pp. 71-116. Kansas City: Federal Reserve Bank of Kansas City.

Terrell, Henry S. 1993. U.S. branches and agencies of foreign banks: A new look. Federal Reserve Bulletin 79 (October): 913-25. 
CHARTS 1-2 ARE U.S. BANKS DECLINING?

CHAAT 1 YES

SHARE OF U.S. FINANCLAL INTERMEDIATION, 1957-93

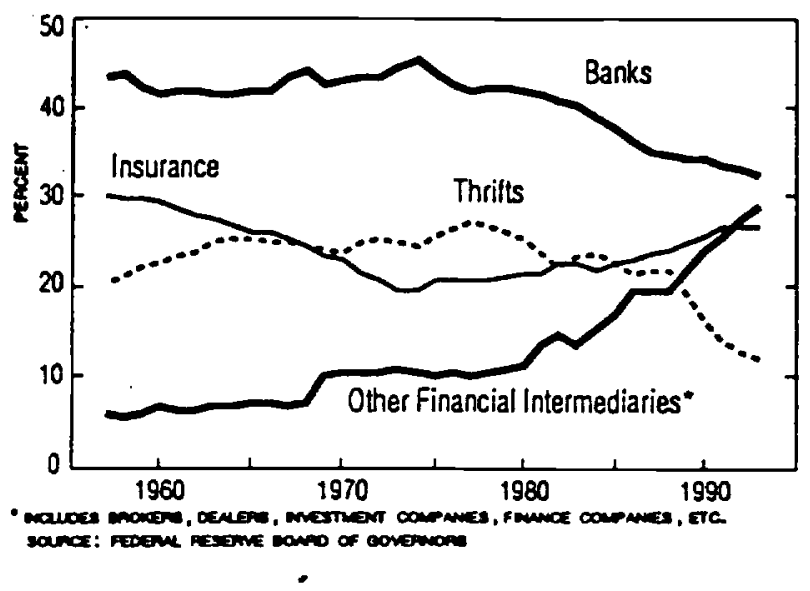

CHAAT 3 TRENDS IN U.S. BANK NONINTEAEST INCOME

AS A PEACENTAGE OF TOTAL INCOME AND ASSETS, 1961-92

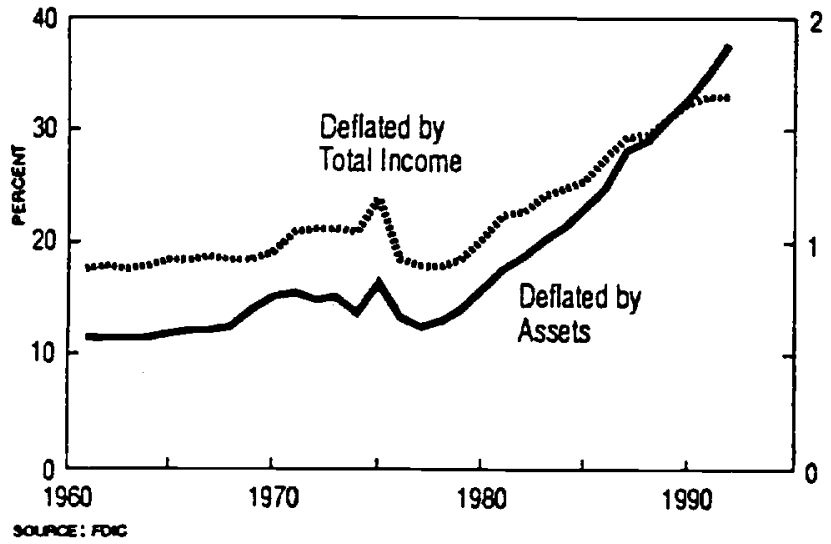

CHART 2 NO

BWNK ASSETS AND LOANS AS A PERCENTAGE

OF NOMINAL GAOSS DOMESTIC PAODUCT, 1957-92

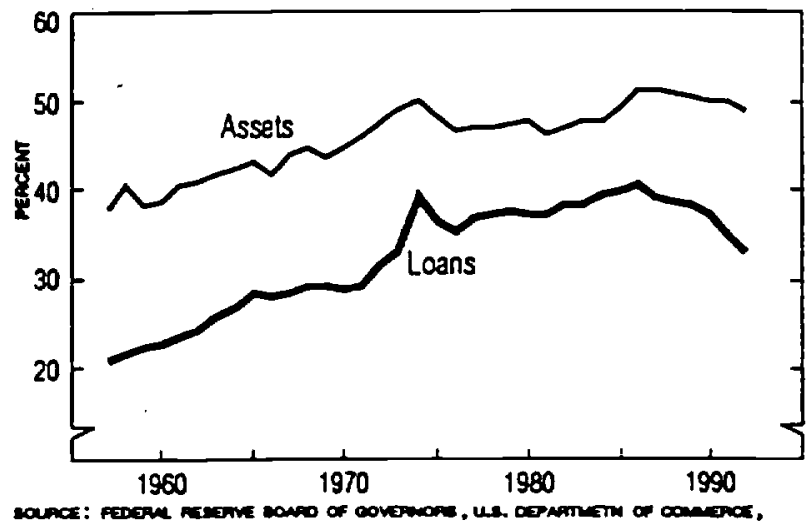
Mo pow

CHART \& BASEL CREDIT EOUNALENTS AS A PERCENTAgE OF U.S. EANKS LOANS, 1983-93

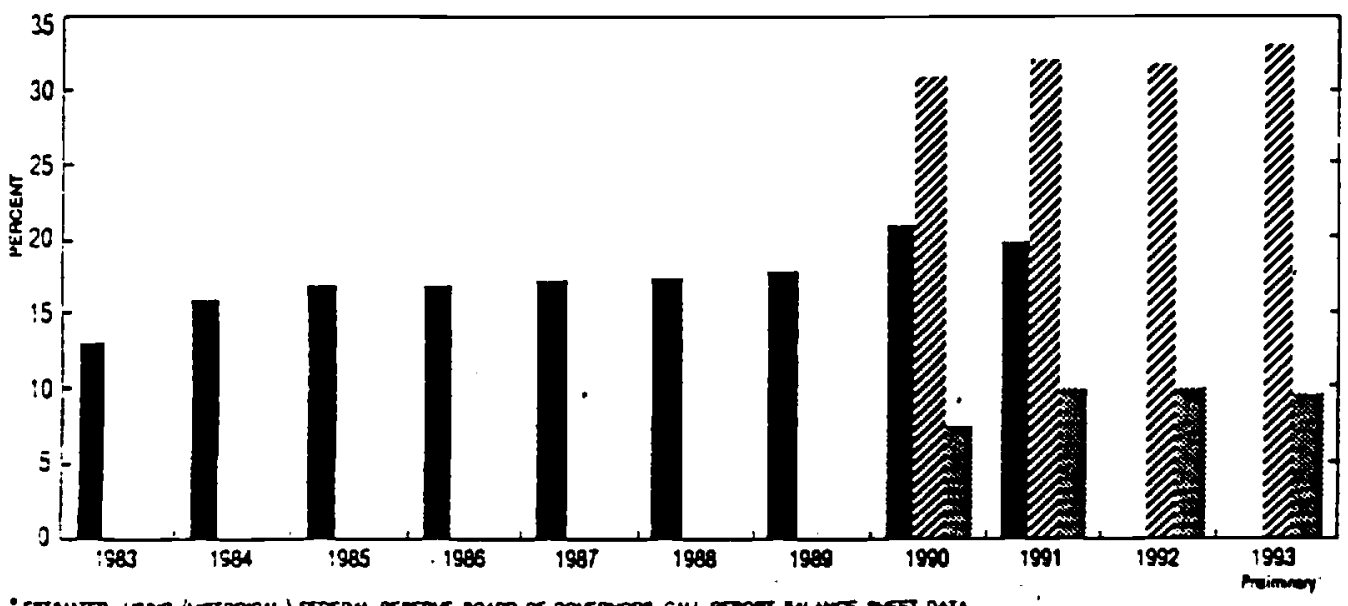

Estinato

Madart

Xas da lo Cervatives"

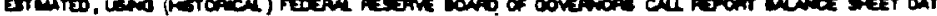

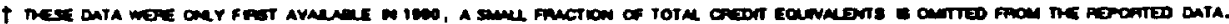

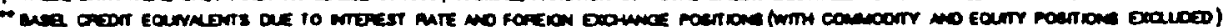

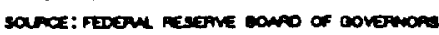


CHART 5 NONINTEREST INCOME CAPITALIZATION CAEDIT EOUNALENTS AS A PERCENTAGE OF U.S. BANK LOANS*

1961.93

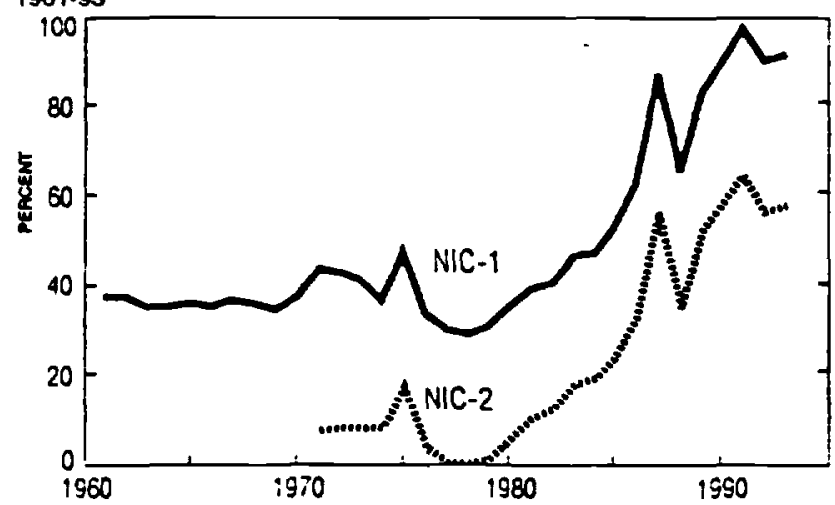

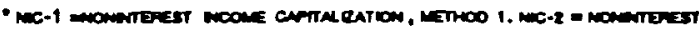
ncone centuleation ietroo 2.

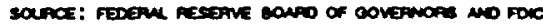

CHART 6 PERCENTAGE OF U.S. BANK ASSETS HELD BY OFFICES OF FOREIGN BANKS LOCATED IN THE U.S. $1963-93$

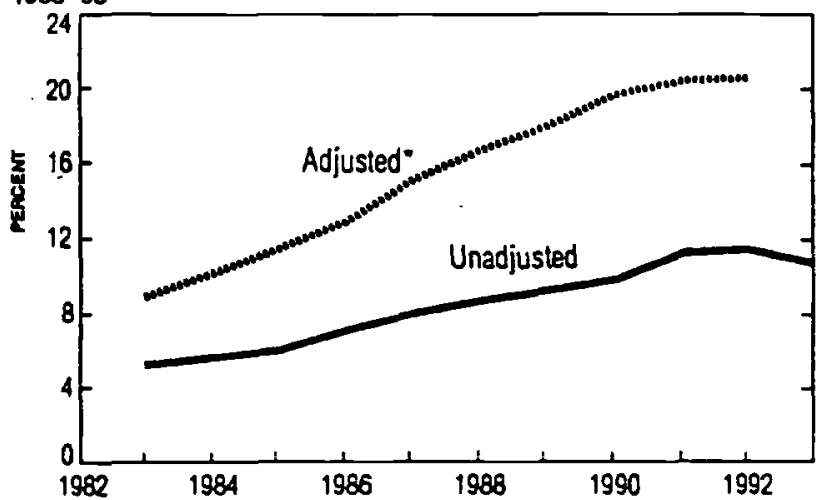

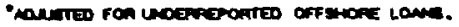

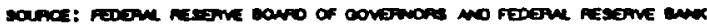

of kew rom

CHARTS 7-8 ADJUSTED VS. UNADJUSTED MEASURES OF U.S. BANK ASSETS

CHART 7 AS A PERCENTAGE OF FINANCIAL INTERMEOUAY ASSETS 1955-93

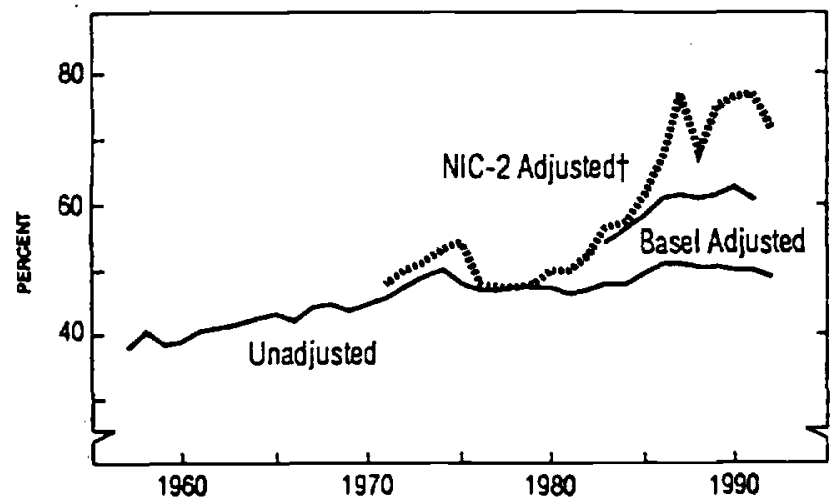

CHART \& AS A PERCENTAGE OF NOMINAL GROSS DOMESTIC PRODUCT 1957-92

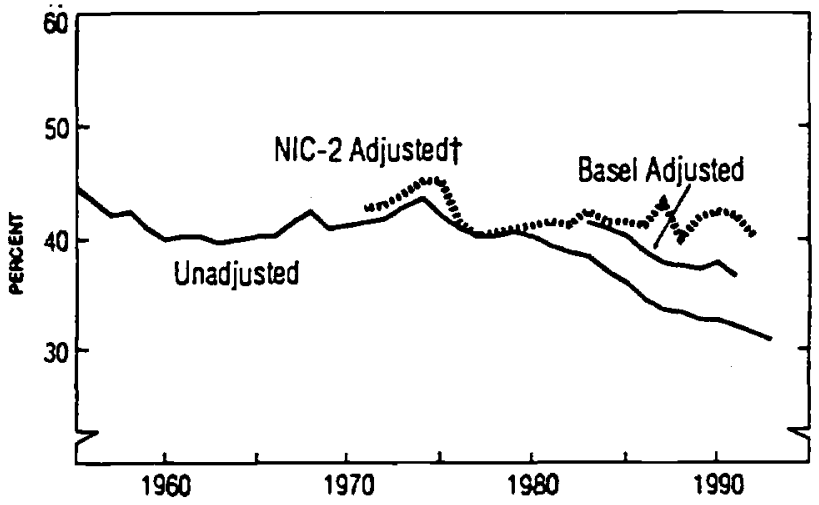

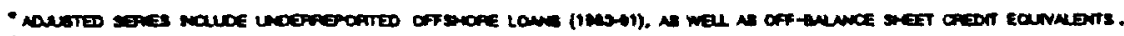

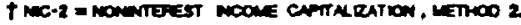

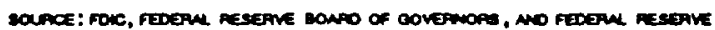
ank of naw rom

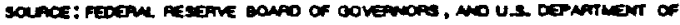
coverance

CHARTS 9-11 U.S. BANKS VS. ALL U.S. FINANCIAL INTERMEDIARIES † WITH LINEAR TIME TRENDS

CHART 9 THE VALUE THAT BANKS ADD TO GROSS DOMESTIC PRODUCT AS A PERCENTAGE OF THE VALUE ADDED BY FINANCIAL INTERMEDIARIES, 1947.90

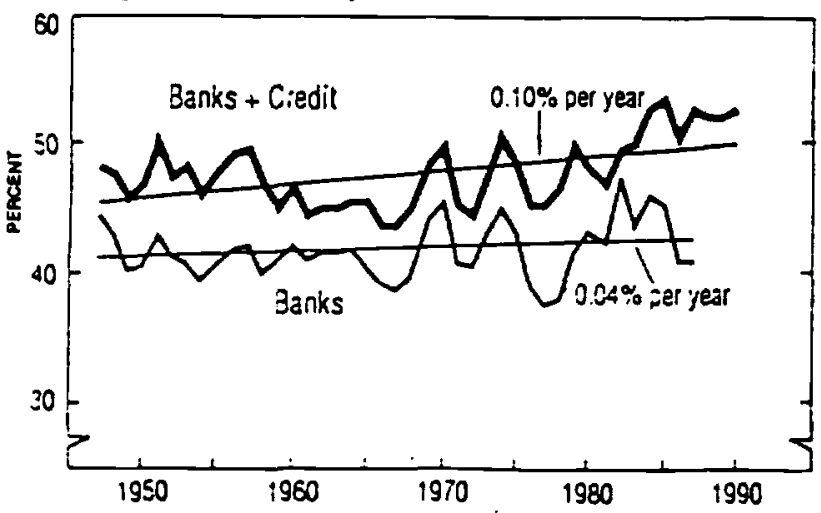

CHART 10 EMPLOYMENT IN BANKING AS A PERCENTAGE OF EMPLOYMENT IN FINANCIAL INTERMEDIARIES," 1947.92

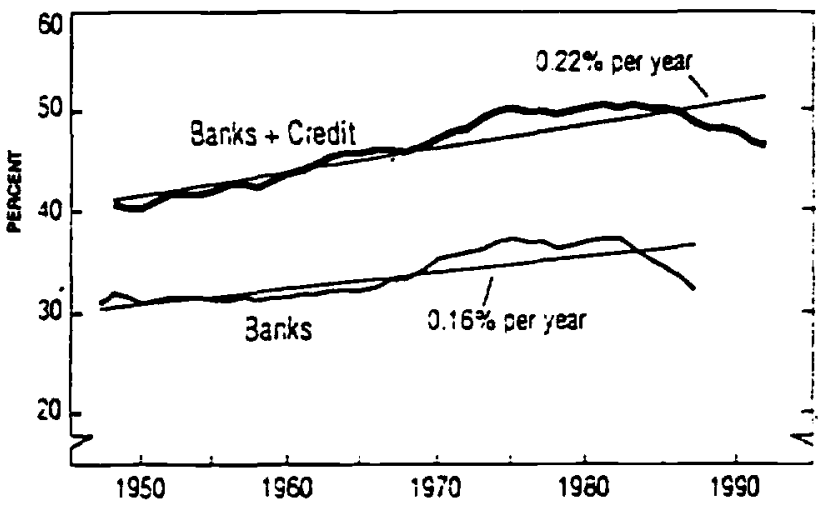


CHART 11 REAL CAPITAL OF BANKS AS A PERCENTAGE OF REAL CAPTIAL OF FINANCIAL INTERMEDIAAIES. NET PLANT AND EOUIPMENT, 1947-92

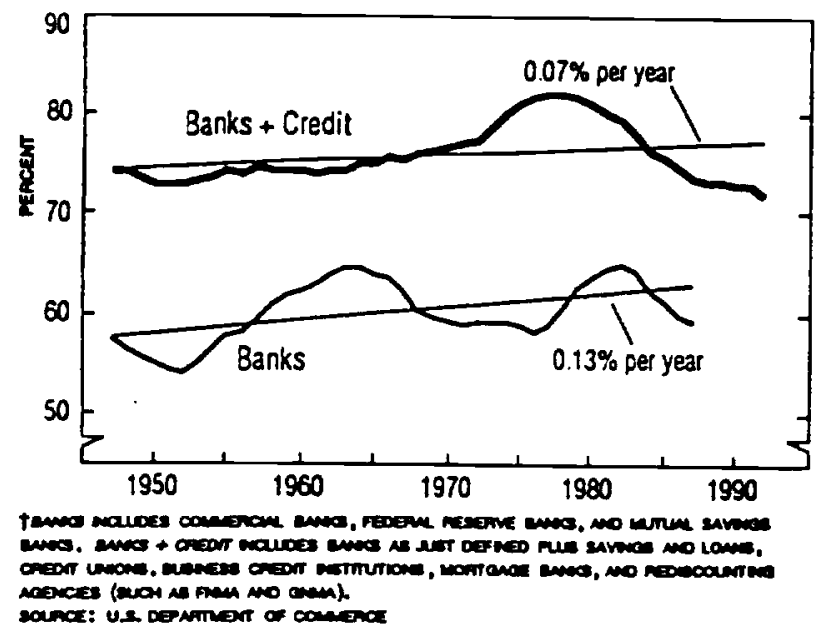

CHART 13 EMPLOYMENT AS A PERCENTAGE OF TOTAL U.S. EMPLOYMENT, " 1947-92

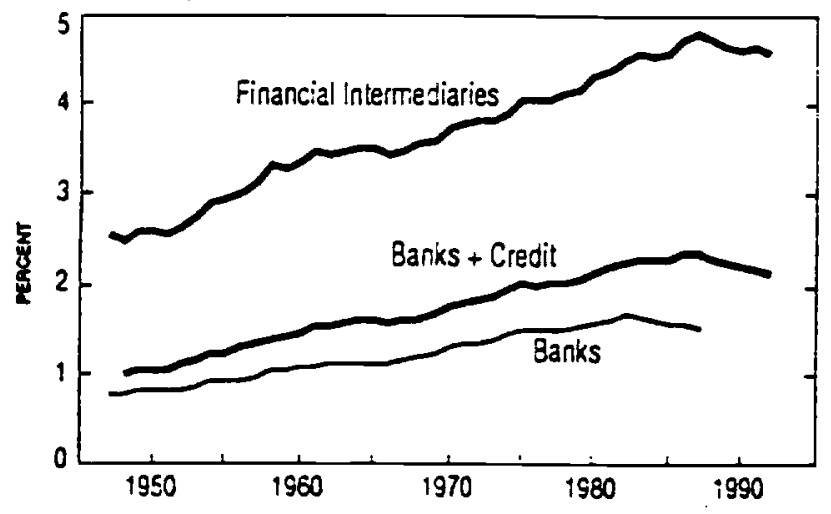

CHARTS 12-14 THE U.S. FINANCIAL INTERMEDIARY SECTORT CHART 12 VALUE ADDED TO FROSS DOMESTIC PRODUCT AS A PERCENTAGE OF GROSS DOMESTIC PRODUCT, 1947- $\infty$

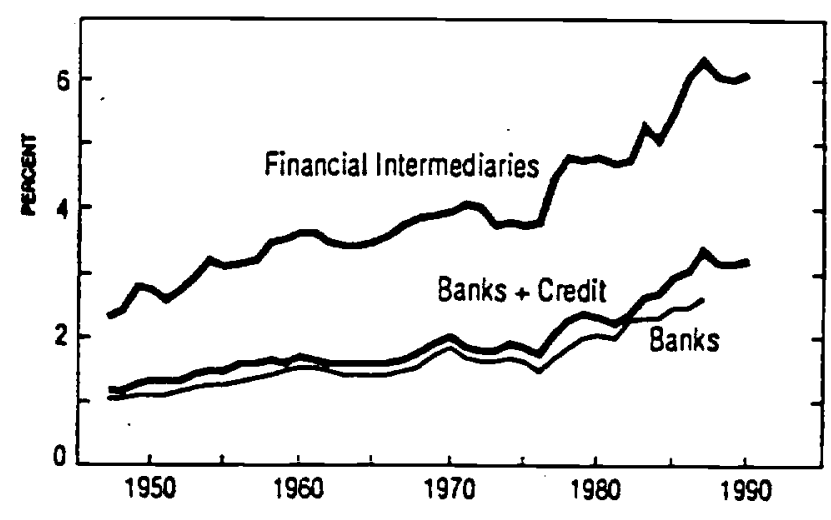

CHART 14 SECTOR REAL CAPTAL AS A PERCENTAGE OF TOTAL U.S. REAL CAPTAL. NET PLANT AND EOUIPMENT, 1947-02

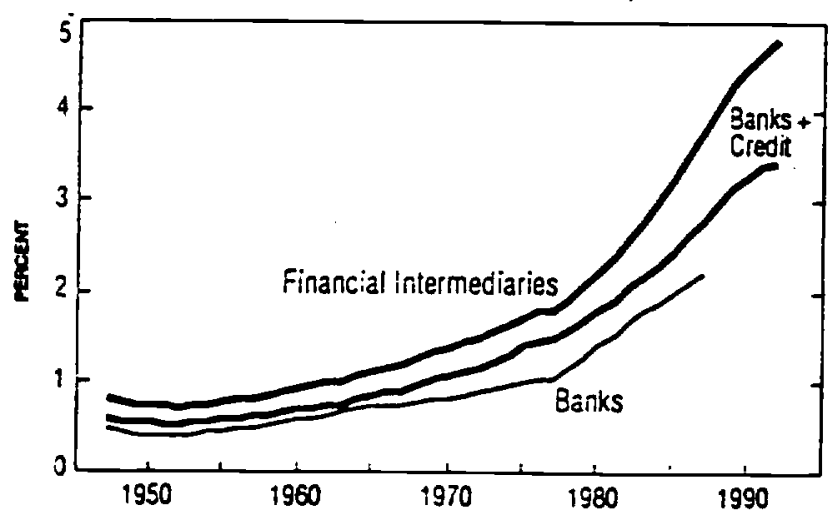

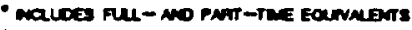

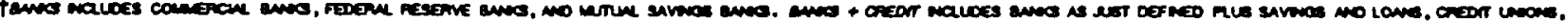

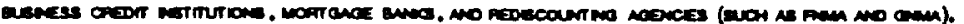

sounce: U.s. Dermanuar of conerince

CHART 15 GROWTH RATES IN U.S. REAL FINANCIAL ASSETS."

THREE-YEAR MOVING AVERMGES, 1957-90

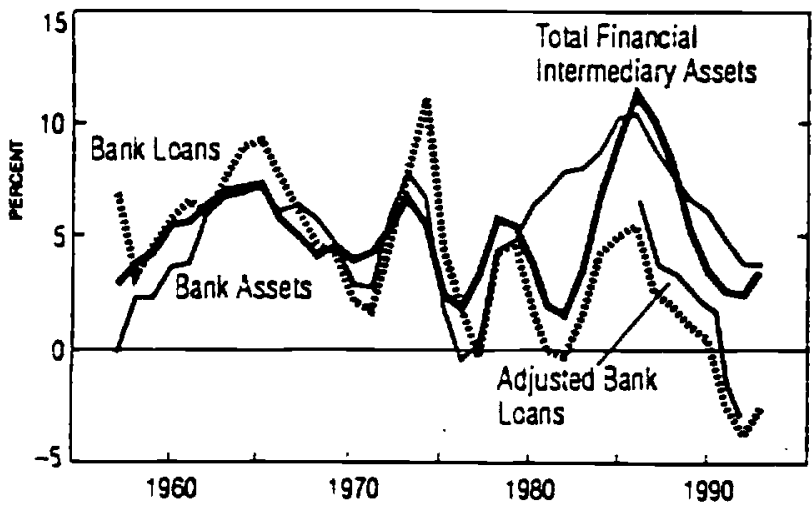

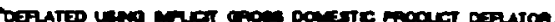

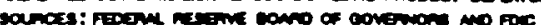


Tables 1-2

Average Annual Percentage Growth Rates

able 1 U.S. Bank Assets and Loans by Capital Adequacy Class*

\begin{tabular}{|c|c|c|c|c|c|c|c|c|}
\hline \multirow[b]{2}{*}{ Year } & \multicolumn{2}{|c|}{$\begin{array}{c}\text { Well- } \\
\text { Capitalizedt }\end{array}$} & \multicolumn{2}{|c|}{$\begin{array}{l}\text { Adequately } \\
\text { Capitalizedt }\end{array}$} & \multicolumn{2}{|c|}{$\begin{array}{c}\text { Under- } \\
\text { Capitalizedt }\end{array}$} & \multicolumn{2}{|c|}{$\begin{array}{c}\text { All } \\
\text { 3anks }\end{array}$} \\
\hline & Assets & Lcans & Assets & Loans & Assets & Loans & Assets & Loans \\
\hline 1990 & 6.95 & 6.72 & 3.62 & 3.90 & -2.24 & -2.46 & 2.62 & 2.38 \\
\hline 1991 & 5.79 & 2.37 & 1.54 & -2.75 & -4.85 & -8.53 & 1.05 & -2.86 \\
\hline 1992 & 3.48 & .88 & 1.66 & -1.65 & -5.12 & -9.09 & 2.63 & -1.24 \\
\hline 1993 & 6.76 & 7.50 & 2.90 & .19 & 1.25 & .40 & 5.39 & 5.40 \\
\hline $\begin{array}{l}\text { Outstanding } \\
\text { Balances at } \\
\text { Eno of } 1993 \\
\text { (\$ Bil.) }\end{array}$ & 3.016 & 1,724 & 433 & 263 & 236 & 153 & 3.691 & 2.440 \\
\hline
\end{tabular}

- Contesticaly suanered aanks. consotioated loreign and somestic operations.

: Mojusied lor SAMEL (Capual acecuacy. asset guality. nanagement arnings, and liquidity) raings.

Sourte Feceral Reserve Baard ol Governors

Table 2 U.S. Bank Real Assets by Asset Size Class*

\begin{tabular}{|c|c|c|c|c|c|c|c|c|}
\hline \multirow[b]{3}{*}{ Year } & \multicolumn{7}{|c|}{ Beginning Real Asset Size Class } & \multirow{3}{*}{$\begin{array}{c}\text { All } \\
\text { Banks }\end{array}$} \\
\hline & \multirow{2}{*}{$\begin{array}{l}\text { so- } \\
50 \text { Mil. }\end{array}$} & \multirow{2}{*}{$\begin{array}{l}\$ 50 \text { Mil.- } \\
100 \text { Mil. }\end{array}$} & \multirow{2}{*}{$\begin{array}{l}\$ 100 \text { Mil.- } \\
250 \text { Mil. }\end{array}$} & \multirow{2}{*}{$\begin{array}{l}\$ 250 \text { Mil.- } \\
1 \text { Bil. }\end{array}$} & \multirow{2}{*}{$\begin{array}{c}\$ 1 \text { Bil.- } \\
10 \text { Bil. }\end{array}$} & \multicolumn{2}{|c|}{ Over \$io Bil. } & \\
\hline & & & & & & Unadjusted & Adjusiedt & \\
\hline 1984 & 6.2 & 4.5 & 4.9 & 6.1 & 9.3 & -2.0 & 2.2 & 5.8 \\
\hline 1985 & 5.7 & 3.6 & 4.7 & 6.9 & 9.9 & 2.2 & 3.4 & 5.4 \\
\hline i986 & 6.6 & 5.3 & 6.8 & 7.8 & $\pi .0$ & 7.1 & 6.9 & 6.6 \\
\hline 1987 & 2.6 & .9 & 1.1 & 2.1 & 3.0 & 1.3 & 19 & 2.0 \\
\hline 1988 & 3.8 & 3.8 & 4.9 & 5.3 & 6.3 & -.6 & .5 & 4.0 \\
\hline 1989 & 3.0 & 2.9 & 2.8 & 4.4 & 3.8 & 2.0 & 2.5 & 3.0 \\
\hline 1990 & 5.4 & 3.4 & 3.1 & 3.8 & 2.7 & -2.2 & $j$ & 4.5 \\
\hline$\$ 991$ & 3.7 & 2.2 & 2.1 & 2.0 & 1.5 & -2.1 & -3.3 & 2.9 \\
\hline Mean & 4.6 & 3.3 & 3.8 & 4.8 & 5.9 & .7 & $: 3$ & 4.3 \\
\hline $\begin{array}{l}\text { Avg. No. } \\
\text { of Firms }\end{array}$ & 6.948 & 2.380 & 1.469 & 607 & 270 & 33 & 33 & 11.700 \\
\hline
\end{tabular}

Serateo gy matcit gress somestic roouct sellatop

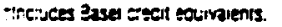

Source Somotroller y the Currency 
Appendix

Supplemental Measures of Bank Growth

This appendix contains material that is helpful for a more detailed understanding of the preceding paper. The tables and charts are listed in the order in which they are referred to in the text.

Table A1

Foreign Bank Share of U.S. Commercial and Industrial Loan Market*

\begin{tabular}{|c|c|c|c|c|c|c|c|c|c|c|c|c|c|c|}
\hline & \multirow[b]{2}{*}{1983} & \multirow[b]{2}{*}{1984} & \multirow[b]{2}{*}{1985} & \multirow[b]{2}{*}{1986} & \multirow[b]{2}{*}{1987} & \multirow[b]{2}{*}{1988} & \multirow[b]{2}{*}{1989} & \multirow[b]{2}{*}{1990} & \multirow[b]{2}{*}{1991} & \multicolumn{4}{|c|}{1992} & \multirow{2}{*}{$\begin{array}{r}1093 \\
01\end{array}$} \\
\hline & & & & & & & & & & 01 & 02 & 03 & 04 & \\
\hline C\&I Loans to U.S. Acoressees & 467 & 512 & 556 & 523 & 654 & 712 & 765 & 804 & $\pi$ & $\pi 6$ & 774 & 771 & 743 & 741 \\
\hline U.S.-Owned Bank Loans & 381 & 402 & 419 & 454 & 445 & 464 & 481 & $4 \pi$ & 428 & 432 & 415 & 408 & 380 & 379 \\
\hline Onshore & 364 & 382 & 401 & 439 & 431 & 446 & 460 & 454 & 407 & 411 & 393 & 386 & 360 & 359 \\
\hline Oflshore & 17 & 20 & 18 & 15 & 15 & 18 & 21 & 22 & 22 & 21 & 22 & 22 & 21 & 20 \\
\hline Foreign-Owned Bank Loanst & 86 & 110 & 137 & 169 & 209 & 248 & 284 & 327 & 348 & 344 & 359 & 363 & 363 & 363 \\
\hline Branches and Agencies & 34 & 43 & 53 & 68 & 86 & 103 & 116 & 127 & 146 & 145 & 145 & 144 & 148 & 142 \\
\hline Subsidiazies & 32 & 35 & 39 & 41 & 44 & 50 & 52 & 52 & 50 & 40 & 49 & 49 & 45 & 46 \\
\hline Estimatec Ottsnore"* & 20 & 31 & 45 & 60 & 79 & 95 & 116 & 148 & 152 & 160 & 164 & 171 & 170 & 175 \\
\hline Ottshore Clarms by Forergn Banks on U.S. Nonbanks & 31 & 49 & 74 & 98 & 130 & 157 & 192 & 246 & 252 & 264 & 272 & 282 & 281 & 289 \\
\hline BIS Reporting Banks' Claims on U.S Nonbanks & 52 & 71 & 93 & 115 & 146 & 181 & 217 & 272 & 278 & 289 & 298 & 307 & 306 & 314 \\
\hline Claims on U.S. Nonbanks by Foreign Branches of U.S. Banks & 21 & 22 & 19 & 17 & 16 & 24 & 25 & 26 & 26 & 25 & 26 & 25 & 25 & $2 \Xi$ \\
\hline Ottshore Loans by Brancres, Agencies, and Subsidiaries & 1 & 2 & 1 & 1 & 1 & 1 & 1 & 1 & 1 & 1 & 1 & 1 & 1 & $\bullet$ \\
\hline Memo: Foreign Share $(\%)$ & 18 & 21 & 25 & 27 & 32 & 35 & 37 & 41 & 45 & 4 & 46 & 47 & 49 & 4 \\
\hline Brancties and Agencies & 7 & 8 & 10 & 11 & 13 & 14 & 15 & 16 & 19 & 19 & 19 & 19 & 20 & $1 \cong$ \\
\hline Subsidiaries & 7 & 7 & 7 & 7 & 7 & 7 & 7 & 6 & 5 & 5 & 6 & 6 & 6 & $\Xi$ \\
\hline Ottsnore & 4 & 6 & 8 & 10 & 12 & 13 & 15 & 18 & 20 & 21 & 21 & 22 & 23 & 24 \\
\hline
\end{tabular}

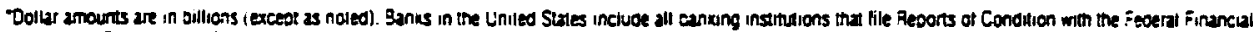
Insitutions Eaminations Councit.

ithetudes branches agencies and subsidiafies.

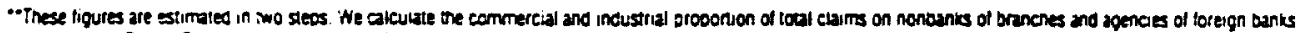

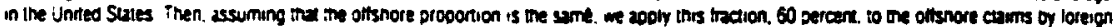

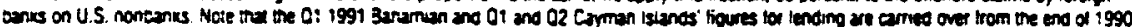

Source. Di. Rama Seth Feceral Reserve Bank of New York 
Table A2

Comparing the Measures

Correcting for Off-Balance Sheet Activities vs. Correcting for Otishore Foreign Lending*

\begin{tabular}{|c|c|c|c|c|}
\hline \multirow[b]{3}{*}{ Year } & \multirow[b]{3}{*}{ Unadjusted } & \multicolumn{3}{|c|}{ Adjusted for } \\
\hline & & \multicolumn{2}{|c|}{ Olt-Balance Sheet Activities } & \multirow{2}{*}{$\begin{array}{l}\text { Underregorting o } \\
\text { Oltsnore Loans: }\end{array}$} \\
\hline & & Basel Melinout & NIC-2 Mestoo": & \\
\hline 1971 & 506.5 & - & $\begin{array}{r}530.3 \\
(4 . T)\end{array}$ & - \\
\hline 1972 & 575.7 & - & $\begin{array}{c}606.9 \\
(5.4)\end{array}$ & - \\
\hline 1973 & 662.4 & 一 & $\begin{array}{r}6970 \\
, \quad(5.2)\end{array}$ & - \\
\hline 1974 & 737.5 & - & $\begin{array}{c}782.2 \\
(6.1)\end{array}$ & - \\
\hline 1975 & 768.8 & - & $\begin{array}{l}868.4 \\
(130)\end{array}$ & - \\
\hline 1976 & 833.2 & - & $\begin{array}{c}853.7 \\
(2.5)\end{array}$ & 一 \\
\hline 1977 & 924.6 & - & $\begin{array}{c}930.3 \\
(.5)\end{array}$ & - \\
\hline 1978 & 1.052 .6 & - & $\begin{array}{r}1.0577 \\
(.5)\end{array}$ & - \\
\hline 1979 & 1.1818 & - & $\begin{array}{r}1.155 .4 \\
\text { (11) }\end{array}$ & - \\
\hline 1980 & 1.289 .9 & - & $\begin{array}{r}1.350 .8 \\
(4 .)\end{array}$ & - \\
\hline 1981 & 1.398 .2 & - & $\begin{array}{r}1.512 .3 \\
(8.2)\end{array}$ & - \\
\hline 1982 & 1.482 .9 & - & $\begin{array}{c}1.6373 \\
(10.4)\end{array}$ & - \\
\hline 1983 & 1.626 .1 & $\begin{array}{r}1.7972 \\
(10.5)\end{array}$ & $\begin{array}{r}1,857 \mathrm{~g} \\
(14.2)\end{array}$ & $\begin{array}{r}1.682 .6 \\
(3.5)\end{array}$ \\
\hline 1984 & 1.800 .1 & $\begin{array}{r}2.036 .5 \\
(13.1)\end{array}$ & $\begin{array}{c}2.094 .3 \\
(163)\end{array}$ & $\begin{array}{r}1.883 .8 \\
(4.6)\end{array}$ \\
\hline 1985 & 1.989 .5 & $\begin{array}{r}2.260 .5^{\prime} \\
(13.5)\end{array}$ & $\begin{array}{r}2.3775 \\
(99.5)\end{array}$ & $\begin{array}{r}2.100 .7 \\
(5.6)\end{array}$ \\
\hline 1986 & 2.187 .6 & $\begin{array}{r}2.479 .1 \\
\text { (13.3) }\end{array}$ & $\begin{array}{r}2.762 a \\
(26.3)\end{array}$ & $\begin{array}{c}2.317 .3 \\
(5.9)\end{array}$ \\
\hline 1987 & 2.323 .0 & $\begin{array}{r}2.530 .0 \\
(13.2)\end{array}$ & $\begin{array}{c}3.335 .1 \\
\text { (43.5] }\end{array}$ & $\begin{array}{r}2.485 .1 \\
(7.0)\end{array}$ \\
\hline 1988 & 2.479 .5 & $\begin{array}{c}2.5076 \\
(13.2)\end{array}$ & $\begin{array}{c}3.473 \\
\text { (253) }\end{array}$ & $\begin{array}{r}2.6772 \\
(8.0)\end{array}$ \\
\hline 1989 & 2.5474 & $\begin{array}{c}3.003 .5 \\
(13.5)\end{array}$ & $\begin{array}{c}3.699 .3 \\
(39.7)\end{array}$ & $\begin{array}{r}2.978 .4 \\
(8.7)\end{array}$ \\
\hline$i 990$ & 2.772 .5 & $\begin{array}{r}3.2014 \\
(155)\end{array}$ & $\begin{array}{r}3.959 .2 \\
i 42.3)\end{array}$ & $\begin{array}{r}3.046 .7 \\
(9.9)\end{array}$ \\
\hline 1991 & 2.356 .8 & $\begin{array}{r}3.2513 \\
(133)\end{array}$ & $\begin{array}{l}4.148 .3 \\
(45.3)\end{array}$ & $\begin{array}{r}3.1175 \\
(9.1)\end{array}$ \\
\hline$; 992$ & 2.951.5. & - & $\begin{array}{r}+0722 \\
(38.1)\end{array}$ & $\begin{array}{r}3.222 .8 \\
(9.2)\end{array}$ \\
\hline
\end{tabular}

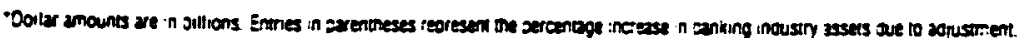

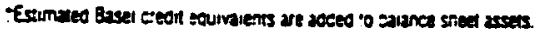

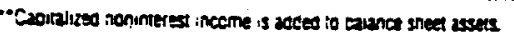

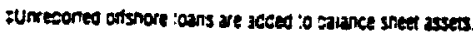

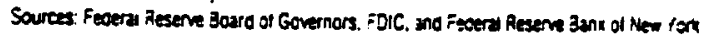


Table A3

Additional Off-Balance Sheet Bank-Related Assets *

\begin{tabular}{lccc}
\hline Year & $\begin{array}{c}\text { Assets of Nonbank } \\
\text { Altiliates ol Bank } \\
\text { Holding Companies }\end{array}$ & $\begin{array}{c}\text { Securitized Consumer } \\
\text { Loans Originated by } \\
\text { Commercial Bankst }\end{array}$ & $\begin{array}{c}\text { Commercial and } \\
\text { Industrial Loans } \\
\text { Sold or Participatedt** }\end{array}$ \\
\hline 1989 & 224 & 22 & 72 \\
1990 & 216 & 40 & 80 \\
1991 & 209 & 57 & 65 \\
1992 & 212 & 66 & 55 \\
1993 & 268 & 83 & 53 \\
\hline
\end{tabular}

- Dotlar amouints are in billions.

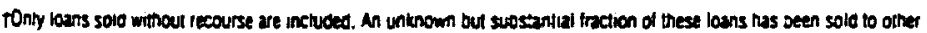

commeresal banis.

"Eased on a sample ol acoroximately 60 large commetcial cants-not ine inoustry aggregale.

Source Fecera Reserve Boalc ol Governors

Tables A4-A6

U.S. Banking Trends

Table A4 Sources of Debt of Nonfinancial Corporations

\begin{tabular}{lcccc}
\hline & 1990 & 1991 & 1992 & $1993^{*}$ \\
\hline Bonds & $37.0 \%$ & $39.7 \%$ & $40.8 \%$ & $41.9 \%$ \\
Mortgages & 6.9 & 6.9 & 5.9 & 5.6 \\
Bank Loans & 18.3 & 17.6 & 16.7 & 16.2 \\
Other Loans & 16.1 & 13.9 & 14.0 & 13.7 \\
Trade Credit & 21.7 & 21.9 & 22.5 & 22.6 \\
\hline
\end{tabular}

Source Soare al Governors of the Federal Reserve Sysen 1993

Table A6 Bank Asset Allocation Ratios

\begin{tabular}{lrrrr}
\hline & 1990 & 1991 & 1992 & $1993^{\circ}$ \\
\hline Loans/Assets & 61.1 & 60.2 & 58.0 & 57.8 \\
Commercial Loans/Assets & 18.2 & 17.1 & 15.5 & 14.6 \\
Securities/Assets & 17.4 & 18.6 & 20.9 & 22.6 \\
Asset Growth Rate & 2.73 & 1.21 & 2.18 & 4.31 \\
\hline
\end{tabular}

Soura Fecerul Aeserve doaro ol Governors ana foIC

- Eirs ine quaners onty
Table A5 Bank Performance

\begin{tabular}{lrrrc}
\hline & 1990 & 1991 & 1992 & $1993^{\circ}$ \\
\hline Return on Assets (\%) & .48 & .53 & .93 & 1.23 \\
Return on Equity (\%) & 7.45 & 7.94 & 13.0 & 15.7 \\
Number of Problem Institutions & 1,012 & 1.016 & 787 & 496 \\
Assets of Problem Institutions (\$ Bil.) & 342 & 528 & 408 & 281 \\
\hline
\end{tabular}

Source FOHC 
Charts A1-A2

An Adjusted vs. An Unadjusted Measure of Bank Assets *

Chart A1 As a Percentage of Financial Intermediary Assets Three-Year Moving Averages, 1955-93

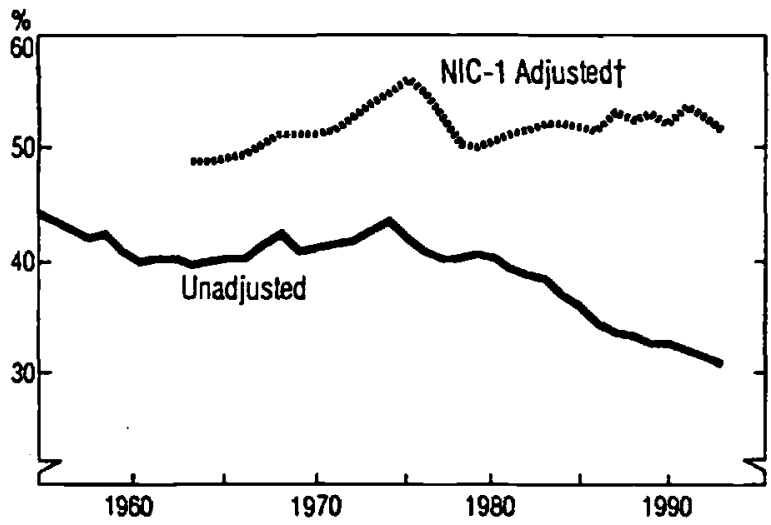

Chart A2 As a Percentage of Nominal Gross Domestic Product 1957-92

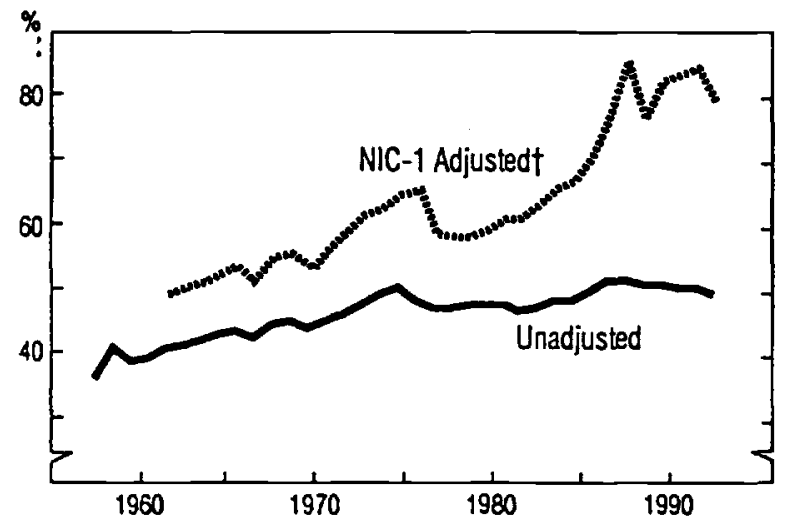

-Adusted benk assess as incressed every year in proportion to the ratio of nonintereat incona to ned interes income

tNIC-1 - nominterst income capitalization, mahod 1.

Sources FoIC, Fedenl Reserve Bcand of Govemors, US. Department of Commerce, and Fedenal Reserve Bank ol Mew York 